\title{
Subacute Toxicity of Nerium oleander Ethanolic Extract in Mice
}

\author{
Rania H. Abdou', Walaa A. Basha² and Waleed F. Khalil ${ }^{3}$ \\ ${ }^{1}$ Department of Forensic Medicine and Toxicology, Faculty of Veterinary Medicine, Suez Canal University, Ismailia, \\ Egypt \\ ${ }^{2}$ Department of Anatomy and Embryology, Faculty of Veterinary Medicine, Suez Canal University, Ismailia, Egypt \\ ${ }^{3}$ Department of Pharmacology, Faculty of Veterinary Medicine, Suez Canal University, Ismailia, Egypt
}

\begin{abstract}
Nerium oleander ( $N$. oleander) is a well-known poisonous shrub that is frequently grown in gardens and public areas and contains numerous toxic compounds. The major toxic components are the cardiac glycosides oleandrin and neriin. The aim of our study was to evaluate the toxic effects of an ethanolic $N$. oleander leaf extract on haematological, cardiac, inflammatory, and serum biochemical parameters, as well as histopathological changes in the heart. $N$. oleander extract was orally administered for 14 and 30 consecutive days at doses of 100 and $200 \mathrm{mg}$ of dried extract $/ \mathrm{kg}$ of body weight in $0.5 \mathrm{~mL}$ of saline. The results showed significant increases in mean corpuscular volume, white blood cell counts, platelet counts, interleukins (IL-1 and IL-6), tumour necrosis factor alpha, C reactive protein, alanine aminotransferase, lactate dehydrogenase, creatine kinase and creatine kinase $\mathrm{MB}$, especially at high doses. Marked pathological changes were perceived in the heart tissue. Thus, it can be concluded that exposure to $N$. oleander leaf extract adversely affects the heart and liver.
\end{abstract}

Key words: Subacute toxicity, Nerium oleander, Ethanolic extract, Cardiac glycosides, Mice

\section{INTRODUCTION}

Nerium oleander ( $N$. oleander) is an evergreen shrub that is frequently grown as an ornamental plant in gardens and public areas. $N$. oleander has linear and leathery leaves that come in various colours, from dark green to grey green with distinct light yellowish veins. Its flowers are fragrant, funnel-shaped and arranged in clusters at the tip of twigs, with white to pink to deep red colours. The fruit is a narrow pod containing many silky-haired seeds (Fig. 1). This plant is native to Mediterranean regions of Africa and Europe (1).

$N$. oleander is well known for its toxicity, as all parts of the plant contain numerous toxic compounds. The major toxic components are the cardiac glycosides oleandrin and

Correspondence to: Waleed F. Khalil, Department of Pharmacology, Faculty of Veterinary Medicine, Suez Canal University, Ismailia 41522, Egypt

E-mail: wk@vet.suez.edu.eg

This is an Open-Access article distributed under the terms of the Creative Commons Attribution Non-Commercial License (http:// creativecommons.org/licenses/by-nc/3.0) which permits unrestricted non-commercial use, distribution, and reproduction in any medium, provided the original work is properly cited. neriin. Plants with red flowers produce more cardiac glycosides than plants with white flowers, especially in the flowering stage (2). Commonly, animal poisoning occurs due to accidental contamination of food or, in some cases, due to consumption of toxic plants by hungry animals (3). Cardiac glycosides inactivate the $\mathrm{Na}^{+} / \mathrm{K}^{+}$ATPase pump on the cytoplasmic membrane of cardiac cells (4).

Despite its toxicity, $N$. oleander has been used as an

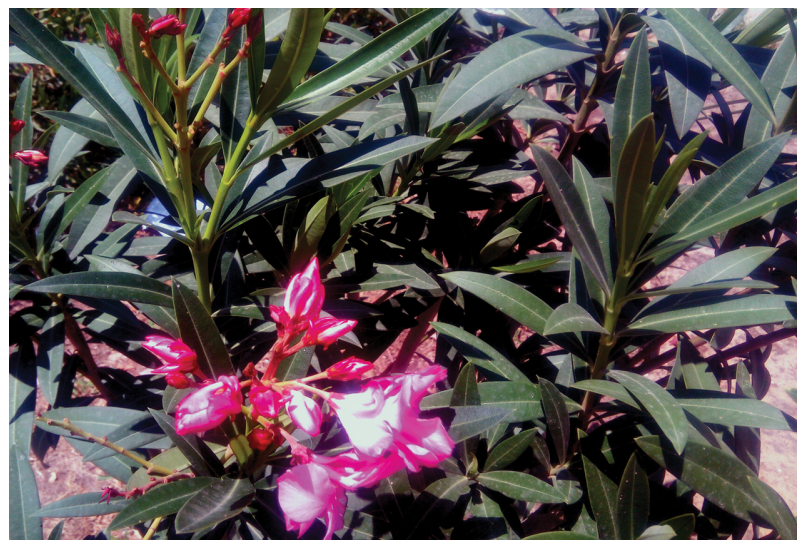

Fig. 1. Nerium oleander (common oleander). 
abortifacient and for the treatment of heart failure, leprosy, malaria, ringworm and indigestion (5). $N$. oleander has insecticidal, molluscicidal, rodenticidal and antibacterial effects (6).

The lethal doses of $N$. oleander leaves were found to differ among animal species, such as sheep and rats (250 and $4,000 \mathrm{mg} / \mathrm{kg}$ body weight, respectively) $(7,8)$. It has been reported that consuming minute amounts of oleander leaves, even $0.005 \%$ of the animal's body weight, is fatal in cattle and horses (3).

The aim of this study was to evaluate the toxic effects of an ethanolic $N$. oleander leaf extract on haematological, cardiac, inflammatory, and serum biochemical parameters, as well as histopathological changes in the heart, after oral administration for 14 and 30 days.

\section{MATERIALS AND METHODS}

Plant material and preparation of the ethanolic extract. Fresh mature green leaves from $N$. oleander bushes with pink flowers were collected from 5 different locations on the Suez Canal University (Ismailia, Egypt) campus during February 2015. The leaves were washed with distilled water, dried in a hot-air oven at $40^{\circ} \mathrm{C}$ and then ground to minute pieces. Exactly $500 \mathrm{~g}$ of ground leaves was extracted several times with $90 \%$ ethanol using a separating funnel. The extract was filtered through filter paper (No. 1) and then evaporated under reduced pressure at $42^{\circ} \mathrm{C}$ using a rotary evaporator (RE111, BUCHI Corporation, DE, USA). The extract was stored in a $5^{\circ} \mathrm{C}$ refrigerator for further phytochemical analysis and toxicological study (9).

Phytochemical analysis. Moisture, ash and crude fibre content of the dried leaves were determined. Moisture and ash contents were estimated by subjecting $100 \mathrm{~g}$ of dried leaves to $90^{\circ} \mathrm{C}$ and $450^{\circ} \mathrm{C}$ for $12 \mathrm{hr}$ and for $5 \mathrm{~min}$, respectively. The percentage of crude fibre was measured according to the standards of the Association of Official Analytical Chemists (10).

In addition, glycosides and oleandrin (the most important bioactive constituents) in the extract were determined and calculated as percentages in $100 \mathrm{~g}$ of dried leaves. The total glycoside content was evaluated using Baljet's reagent according to the method described by El-Olemy et al (11). After purification of the extract by lead acetate, $\mathrm{Na}_{2} \mathrm{HPO}_{4}$ and filtration, Baljet's reagent was added, and the intensity of the produced reddish colour was then measured at $495 \mathrm{~nm}$ using a Shimadzu UV-2600 spectrophotometer. The concentration was calculated using a digitoxin standard curve (0.1$1.6 \mathrm{mg} / \mathrm{mL}$ ). Oleandrin was extracted from $N$. oleander ethanolic extract with 1-naphthoyl chloride and quantified using HPLC (Agilent Infinity 1260) with a fluorescence detector (excitation $=220 \mathrm{~nm}$ and emission $=345 \mathrm{~nm}$ ) equipped with a $\mathrm{C} 18$ reverse column according to the method described by
Tor et al (12). The oleandrin standard was purchased from Sigma Chemical Co (St. Louis, MO, USA).

Acute oral toxicity $\left(\mathbf{L D}_{\mathbf{5 0}}\right.$ evaluation). The median lethal dose $\left(\mathrm{LD}_{50}\right)$ of the $N$. oleander ethanolic extract was determined using $12 \mathrm{BALB} / \mathrm{c}$ male mice. The animal management protocol and that experimental design were accepted by the Research Ethics Committee of the Faculty of Veterinary Medicine, Suez Canal University (Approval number 2016090). Graduated doses between 0.5 and $3.0 \mathrm{~g}$ of dried extract $/ \mathrm{kg}$ b.w. were used after reconstitution in $0.5 \mathrm{~mL}$ of saline and administered orally by stomach gavage. The animals were observed for $24 \mathrm{hr}$ for apparent signs of toxicity and mortality. The $\mathrm{LD}_{50}$ for the extract was determined according to the modified up-and-down technique (13), and its value was calculated using the acute oral toxicity statistical program (AOT425, version 1.0, USEPA, Washington DC, USA).

Animals and experimental design. A total of 30 male mice with body weights of 20-25 g were purchased from the Laboratory Animal Centre of the Faculty of Veterinary Medicine, Suez Canal University. The mice were housed in polypropylene cages (10 mice/cage) in a ventilated room with a controlled light $(12 \mathrm{hr})$ : dark (12 hr) cycle and temperature $\left(25 \pm 2^{\circ} \mathrm{C}\right)$. Food and water were provided ad libitum. The animal management protocol and the experimental design were accepted by the Research Ethics Committee of the Faculty of Veterinary Medicine, Suez Canal University (Approval number 2016090).

After one week of acclimatization, mice were randomly divided into 3 different groups: 10 animals in each group. Of these 10 mice, 5 were used for the 14-day study, and the other 5 were used for the 30-day experiment. The mice in the 1st group were administered normal saline and kept as controls. The animals in the 2 nd and 3rd groups were administered $N$. oleander ethanolic extract using intragastric gavage at doses of 100 and $200 \mathrm{mg}$ dried extract $/ \mathrm{kg}$ body weight, respectively, in $0.5 \mathrm{~mL}$ of saline. These doses were determined to be less than one tenth $(1 / 10)$ of the calculated $\mathrm{LD}_{50}$ in this study (14) to avoid any possible toxin accumulation in the mice. Nerium extract was administered daily for 14 and 30 consecutive days from the beginning of the treatment.

Blood collection, serum and tissue preparation. After 14 and 30 days of oral administration of $N$. oleander, blood samples were collected from the postorbital plexus $24 \mathrm{hr}$ after the last treatment. The blood samples were collected in EDTA tubes to investigate the haematological parameters and in non-EDTA-containing tubes to prepare serum for biochemical analysis.

The mice were sacrificed by decapitation, and heart samples were rapidly excised for histopathological evaluation. 
Blood and serum biochemical analysis. Blood parameters, including red blood cells (RBCs), haemoglobin concentration $(\mathrm{Hb})$, haematocrit value (HCT), mean corpuscular volume (MCV), mean corpuscular haemoglobin $(\mathrm{MCH})$, mean corpuscular haemoglobin concentration (MCHC), white blood cells (WBCs), lymphocytes, and platelet count (PLT), were estimated. Alanine aminotransferase (ALT), creatinine, and inflammatory markers, including interleukin 1 (IL-1), interleukin 6 (IL-6), tumour necrosis factor $\alpha$ $(\mathrm{TNF}-\alpha)$ and $\mathrm{C}$ reactive protein (CRP), were measured in serum. Myocardial damage markers, including lactate dehydrogenase (LDH), creatine kinase (CK) and creatine kinase MB (CK-MB), were also evaluated. ALT, creatinine, CRP, CK, CK-MB and LDH were measured using a Roche/Hitachi Cobas C311 automatic analyzer. Each parameter was analysed according to the method and the instructions provided by the manufacturer of the automated analyzer. The CBC was analysed using an automated Sysmex KX-21N haematology analyzer according to the manufacturer's instructions. TNF, IL-1 and IL-6 were estimated by an ELISA reader in accordance with the manufacturer's directions. All machines and equipment were calibrated and standardized periodically before running the tests.

Histopathological evaluation. Heart muscles were washed with normal saline solution $(0.9 \% \mathrm{NaCl}$ in distilled water) and then fixed in $10 \%$ buffered formalin. After standard processing of the tissue, $5 \mu \mathrm{m}$ sections were prepared and stained with haematoxylin and eosin. The slides were then examined under a light microscope to investigate the histopathological changes. All images were captured with a calibrated standard digital microscope camera (ISH1000 digital microscope camera, Fuzhou Tucsen Photonics Co., Fujian, China) using an CX21 microscope (Olympus Co., Tokyo, Japan), with "IS Capture" software (Olympus Co.) for image capture and enhancement. A semi-quantitative scoring system for myocardial damage was applied based on the severity and extent of the lesions observed in each mouse (15). Briefly, for each myocardial slide, histopathological signs of inflammation and/or myocarditis were scored on a fivedegree scale ranging from 0 to $4+$. A score of zero indicated no or doubtful presence of lesions in each category. While a score of $1+$ described a limited focal distribution of lesions, scores of $2+$ to $3+$ denoted intermediate rigorousness with multiple lesions, and a score of $4+$ indicated the presence of coalescing and extensive lesions throughout the entire examined myocardial tissue. A maximum score of 16 was possible using this scoring system.

Statistical analysis. Data were examined using oneway ANOVA followed by Duncan's post hoc test to detect significant differences at a probability level of $5 \%(p \leq$ $0.05)$. All data were expressed as the mean $\pm \mathrm{SE}$.

\section{RESULTS}

Phytochemical analysis. Moisture, ash, crude fibre, total glycoside and oleandrin contents were estimated in dried leaves of $N$. oleander and are presented in Table 1. The total glycoside and oleandrin contents were 1,944 and $82 \mathrm{mg} / 100 \mathrm{gm}$ dried leaves, respectively.

$L D_{50}$ experiment results. Oral administration of $N$. oleander ethanolic extract up to a dose of $3 \mathrm{~g} / \mathrm{kg}$ b.w. revealed neither toxic signs nor death within $24 \mathrm{hr}$ of extract administration. Furthermore, there were no apparent signs of delayed toxicity when the mice were observed for an additional 14 days.

Table 1. Phytochemical analysis of Nerium oleander dried leaves

\begin{tabular}{cc}
\hline \hline Consistent of dried leaves & Percentage \\
\hline Moisture & 5.13 \\
Ash & 9.06 \\
Crude fiber & 20.66 \\
Glycosides & 1.94 \\
Oleandrin & 0.0082 \\
\hline
\end{tabular}

Table 2. Blood parameters at 14 days post oral treatment with Nerium oleander ethanolic extract

\begin{tabular}{lccc}
\hline \hline Parameter/Group & \multicolumn{1}{c}{ Control } & Low dose & High dose \\
\hline RBCs $\left(10^{6}\right) / \mu \mathrm{L}$ & $7.90 \pm 0.20^{\mathrm{a}}$ & $7.52 \pm 0.24^{\mathrm{a}}$ & $7.53 \pm 0.30^{\mathrm{a}}$ \\
$\mathrm{Hb} \mathrm{g/dL}$ & $10.78 \pm 0.31^{\mathrm{a}}$ & $10.64 \pm 0.21^{\mathrm{a}}$ & $10.52 \pm 0.22^{\mathrm{a}}$ \\
$\mathrm{HCT} \%$ & $38.50 \pm 0.77^{\mathrm{a}}$ & $37.44 \pm 0.46^{\mathrm{a}}$ & $36.80 \pm 0.95^{\mathrm{a}}$ \\
$\mathrm{MCV} \mathrm{fL}$ & $48.38 \pm 0.27^{\mathrm{a}}$ & $47.86 \pm 0.48^{\mathrm{a}}$ & $47.98 \pm 0.75^{\mathrm{a}}$ \\
MCH pg & $12.22 \pm 0.23^{\mathrm{b}}$ & $12.76 \pm 0.56^{\mathrm{b}}$ & $13.90 \pm 0.55^{\mathrm{a}}$ \\
MCHC g/dL & $27.12 \pm 0.45^{\mathrm{b}}$ & $27.72 \pm 0.46^{\mathrm{ab}}$ & $28.86 \pm 0.63^{\mathrm{a}}$ \\
WBC $\left(10^{3}\right) / \mu \mathrm{L}$ & $10.36 \pm 0.34^{\mathrm{a}}$ & $10.12 \pm 0.23^{\mathrm{a}}$ & $9.12 \pm 0.49^{\mathrm{b}}$ \\
Lymphocyte \% & $95.60 \pm 0.97^{\mathrm{a}}$ & $93.20 \pm 1.11^{\mathrm{b}}$ & $91.00 \pm 0.91^{\mathrm{b}}$ \\
PLT $\left(10^{3}\right) / \mu \mathrm{L}$ & $955.60 \pm 15.95^{\mathrm{a}}$ & $1031.00 \pm 70.03^{\mathrm{a}}$ & $1059.20 \pm 89.06^{\mathrm{a}}$ \\
\hline
\end{tabular}

Data are expressed as means $\pm S E M, n=5$. Values having different alphabetic superscripts within the same row are significantly different $(p \leq 0.05)$. 
Table 3. Blood parameters on 30 days post oral treatment with Nerium oleander ethanolic extract

\begin{tabular}{|c|c|c|c|}
\hline Parameter/Group & Control & Low dose & High dose \\
\hline $\operatorname{RBCs}\left(10^{6}\right) / \mu \mathrm{L}$ & $8.13 \pm 0.53^{\mathrm{a}}$ & $8.17 \pm 0.25^{\mathrm{a}}$ & $7.86 \pm 0.33^{\mathrm{a}}$ \\
\hline $\mathrm{Hb} \mathrm{g} / \mathrm{dL}$ & $11.72 \pm 0.58^{\mathrm{a}}$ & $11.68 \pm 0.53^{\mathrm{a}}$ & $11.14 \pm 0.79^{\mathrm{a}}$ \\
\hline НСТ\% & $41.02 \pm 2.07^{\mathrm{a}}$ & $40.68 \pm 0.77^{\mathrm{a}}$ & $42.28 \pm 0.90^{\mathrm{a}}$ \\
\hline MCV fL & $49.14 \pm 0.69^{b}$ & $48.78 \pm 0.94^{b}$ & $53.78 \pm 0.39^{\mathrm{a}}$ \\
\hline $\mathrm{MCH}$ pg & $14.02 \pm 0.37^{\mathrm{a}}$ & $14.28 \pm 0.29^{\mathrm{a}}$ & $14.90 \pm 0.47^{\mathrm{a}}$ \\
\hline $\mathrm{MCHC} \mathrm{g} / \mathrm{dL}$ & $28.30 \pm 0.34^{\mathrm{a}}$ & $29.82 \pm 0.56^{\mathrm{a}}$ & $28.80 \pm 0.91^{\mathrm{a}}$ \\
\hline WBC $\left(10^{3}\right) / \mu \mathrm{L}$ & $10.70 \pm 0.88^{b}$ & $9.04 \pm 1.04^{\mathrm{b}}$ & $14.14 \pm 1.09^{\mathrm{a}}$ \\
\hline lymphocyte \% & $91.00 \pm 2.12^{b}$ & $95.00 \pm 1.08^{\mathrm{a}}$ & $94.60 \pm 0.88^{\mathrm{a}}$ \\
\hline $\operatorname{PLT}\left(10^{3}\right) / \mu \mathrm{L}$ & $771.00 \pm 88.69^{b}$ & $789.60 \pm 66.51^{\mathrm{b}}$ & $1082.40 \pm 129.07^{\mathrm{a}}$ \\
\hline
\end{tabular}

Data are expressed as means $\pm S E M, n=5$. Values having different alphabetic superscripts within the same row are significantly different $(p \leq 0.05)$.

Blood parameter estimation results. After 14 days of oral treatment with $N$. oleander alcoholic extract, blood parameters showed a significant increase in $\mathrm{MCH}$ and a decrease in WBCs in the high-dose group, with a significant decrease in lymphocytes (\%) in both the low- and high-dose groups. After 30 days of oral administration, blood parameters revealed significant elevations of $\mathrm{MCV}$, WBCs and PLT in the high-dose group, with significant decreases in lymphocytes (\%) in the low- and high-dose groups compared to those in the control group (Table 2, 3).
Serum biochemical parameter estimation results. IL-1, IL-6, TNF- $\alpha$, CK, and CK-MB were significantly increased in the high-dose group after 14 days of treatment, while CRP and LDH were significantly increased in both the low- and high-dose groups. After 30 days of administration, IL-6, TNF- $\alpha$, CRP, ALT, LDH, CK and CK-MB levels were significantly increased in both the low- and high-dose groups, while IL-1 was only significantly increased in the high-dose group compared to those in the control group (Table 4, 5).

Table 4. Serum biochemical parameters after 14 days from oral treatment with Nerium oleander alcoholic extract

\begin{tabular}{|c|c|c|c|}
\hline Parameter/Group & Control & Low dose & High dose \\
\hline IL1 pg/mL & $2.72 \pm 0.26^{\mathrm{b}}$ & $2.76 \pm 0.139^{b}$ & $5.12 \pm 0.440^{\mathrm{a}}$ \\
\hline IL6 pg/mL & $9.46 \pm 0.30^{\mathrm{b}}$ & $9.34 \pm 0.320^{b}$ & $15.42 \pm 0.886^{\mathrm{a}}$ \\
\hline $\mathrm{TNF} \alpha \mathrm{pg} / \mathrm{mL}$ & $8.70 \pm 0.24^{\mathrm{b}}$ & $9.12 \pm 0.214^{\mathrm{b}}$ & $12.36 \pm 0.594^{\mathrm{a}}$ \\
\hline CRP & $3.74 \pm 0.37^{\mathrm{c}}$ & $5.72 \pm 0.599^{\mathrm{b}}$ & $8.24 \pm 0.315^{\mathrm{a}}$ \\
\hline ALT & $44.20 \pm 5.56^{\mathrm{a}}$ & $33.40 \pm 2.221^{\mathrm{b}}$ & $47.80 \pm 3.795^{\mathrm{a}}$ \\
\hline Creatinine & $0.48 \pm 0.05^{\mathrm{a}}$ & $0.48 \pm 0.048^{\mathrm{a}}$ & $0.50 \pm 0.041^{\mathrm{a}}$ \\
\hline LDH & $54.00 \pm 3.24^{\mathrm{c}}$ & $63.60 \pm 2.183^{\mathrm{b}}$ & $84.20 \pm 4.990^{\mathrm{a}}$ \\
\hline $\mathrm{CK}$ & $237.20 \pm 11.60^{\mathrm{b}}$ & $259.20 \pm 15.489^{b}$ & $426.40 \pm 47.646^{\mathrm{a}}$ \\
\hline $\mathrm{CK} \mathrm{Mb}$ & $16.40 \pm 1.20^{\mathrm{b}}$ & $20.20 \pm 0.753^{\mathrm{b}}$ & $116.20 \pm 7.973^{\mathrm{a}}$ \\
\hline
\end{tabular}

Data are expressed as means \pm SEM, $n=5$. Values having different alphabetic superscripts within the same row are significantly different $(p \leq 0.05)$.

Table 5. Serum biochemical parameters after 30 days from oral treatment with Nerium oleander ethanolic extract

\begin{tabular}{lcrc}
\hline \hline Parameter/Group & Control & Low dose & High dose \\
\hline IL1 pg/mL & $2.92 \pm 0.29^{\mathrm{b}}$ & $3.66 \pm 0.211^{\mathrm{b}}$ & $8.08 \pm 0.511^{\mathrm{a}}$ \\
IL6 pg/mL & $9.44 \pm 0.30^{\mathrm{c}}$ & $12.40 \pm 0.623^{\mathrm{b}}$ & $18.74 \pm 0.631^{\mathrm{a}}$ \\
TNF $\alpha \mathrm{pg} / \mathrm{mL}$ & $8.64 \pm 0.28^{\mathrm{c}}$ & $11.24 \pm 0.446^{\mathrm{b}}$ & $16.66 \pm 0.290^{\mathrm{a}}$ \\
CRP & $3.84 \pm 0.43^{\mathrm{c}}$ & $6.44 \pm 0.431^{\mathrm{b}}$ & $9.00 \pm 0.922^{\mathrm{a}}$ \\
ALT & $47.20 \pm 4.03^{\mathrm{c}}$ & $58.20 \pm 2.955^{\mathrm{b}}$ & $72.00 \pm 5.745^{\mathrm{a}}$ \\
Creatinine & $0.50 \pm 0.06^{\mathrm{ab}}$ & $0.40 \pm 0.058^{\mathrm{b}}$ & $0.58 \pm 0.048^{\mathrm{a}}$ \\
LDH & $53.80 \pm 3.66^{\mathrm{c}}$ & $95.20 \pm 1.844^{\mathrm{b}}$ & $116.40 \pm 5.141^{\mathrm{a}}$ \\
CK & $239.80 \pm 14.60^{\mathrm{c}}$ & $357.80 \pm 29.786^{\mathrm{b}}$ & $550.40 \pm 75.563^{\mathrm{a}}$ \\
CK Mb & $16.80 \pm 1.18^{\mathrm{c}}$ & $26.00 \pm 1.472^{\mathrm{b}}$ & $42.00 \pm 4.546^{\mathrm{a}}$ \\
\hline
\end{tabular}

Data are expressed as means $\pm S E M, n=5$. Values having different alphabetic superscripts within the same row are significantly different $(p \leq 0.05)$. 
Histopathological results. In the control group, heart muscle formed of myocytes arranged into fascicles with striations and peripheral oval nuclei separated by loose connective tissue and thin vessels (Fig. 2A, 2D).

After 14 days of oral administration of a low dose of $N$. oleander alcoholic extract, heart muscles showed diffuse mild inter-fascicular oedema with mildly congested vessels. In addition, many degenerated myocytes showed fragmentation of myofibrils (Fig. 2B). In contrast, in the high-dose group, the heart muscles showed moderate interfascicular oedema with dilated congested vessels and few degenerated myocytes with focal striation loss and focal vacuolar degeneration (Fig. 2C).

After 30 days of oral administration of a low dose of $N$. oleander extract, the heart muscles showed focal mild inter-fascicular oedema with mildly congested vessels and very few degenerated myocytes (Fig. 2E). In contrast, in the high-dose group, the heart muscles showed focal marked inter-fascicular oedema with dilated congested vessels (black arrow) and moderately degenerated myocytes with vacuolation of the muscle. Additionally, a few myofibrils showed striation loss (arrow head) (Fig. 2F). Table 6 shows semi-quantitative histopathological scoring of mouse car-

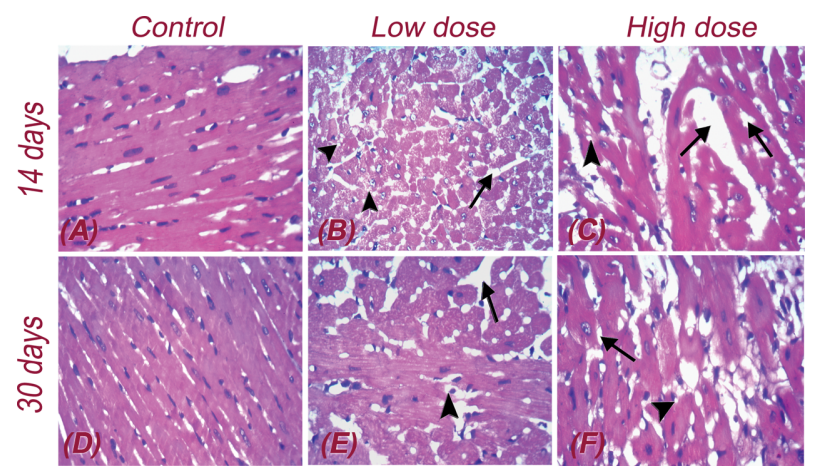

Fig. 2. Histopathological results on $14(A, B, C)$ and 30 days (D, E, F) post oral treatment with Nerium oleander ethanolic extract. All slides were stained with Hematoxylin and Eosin dyes and captured with high power field of 400x. Arrows and arrowheads point out the pathological changes such as interfascicular edema (black arrow) and degenerated myocytes with vacuolation of myofibrils (arrow head).

Table 6. Semi-quantitative histopathological scoring of myocardial damage after 14 and 30 days from oral treatment with Nerium oleander alcoholic extract in mice

\begin{tabular}{ccc}
\hline \hline Groups & 14 days & 30 days \\
\hline Control & $0.0 \pm 0.00^{\mathrm{b}}$ & $0.2 \pm 0.26^{\mathrm{c}}$ \\
Low dose & $2.0 \pm 0.41^{\mathrm{a}}$ & $2.6 \pm 0.32^{\mathrm{b}}$ \\
High dose & $3.2 \pm 0.75^{\mathrm{a}}$ & $4.6 \pm 0.66^{\mathrm{a}}$ \\
\hline
\end{tabular}

Data are expressed as means \pm SEM, $n=5$. Values having different alphabetic superscripts within the same column are significantly different $(p \leq 0.05)$. diac lesions at 14 and 30 days after $N$. oleander extract administration.

\section{DISCUSSION}

Oleander poisoning is a common problem in many parts of the world. Oleander toxicity is due to oleandrin (the main cardiac glycoside of oleander) and neriin, which cause damage by inhibiting the plasmalemmal $\mathrm{Na}^{+} / \mathrm{K}^{+}$ATPase. $\mathrm{Na}^{+} / \mathrm{K}^{+}$-ATPase is responsible for maintaining the membrane potential of cardiac muscle cells, and its inhibition leads to necrosis of myocytes (16). In the current study, we examined the haematological, biochemical and histopathological changes that occur after administration of an $N$. oleander leaf ethanolic extract in mice. Haematological analysis showed a significant increase in MCV, WBCs and PLT, and these results are consistent with the results of other researchers $(17,18)$. The increase in MCV is an indication of a pathological condition called "macrocytosis", which is due to liver injury that may be caused by free radicals resulting from $N$. oleander administration (18). The liberation of free radicals into the blood may also influence the circulating cells and significantly altera their numbers (19). Significant decreases in RBC, $\mathrm{Hb}$ and PCV were recorded in female mice treated with $N$. oleander alkaloid extracts (20). The author attributed these declines to the disruption of factors that influence erythropoiesis or to the rupture of the RBC membrane. However, the effect of $N$. oleander on blood parameters remains controversial among researchers $(18,20)$. Higher platelet and white blood cell counts may act as markers of proinflammatory conditions (21).

These results revealed significant increases in IL-6, TNF- $\alpha$, CRP, ALT, LDH, CK and CK-MB levels in both the low- and high-dose groups, while IL-1 was significantly increased only in the high-dose group compared to the control group. Increased serum concentrations of the inflammatory marker CRP and pro-inflammatory cytokines (IL-1, IL- 6 and TNF- $\alpha$ ) are observed during chronic heart failure and mediate both immune and inflammatory responses, inducing apoptosis, in myocardial cells (22) (23). Toxic substances induce pro-inflammatory cytokines through the activation of macrophages (24). The proinflammatory cytokine TNF- $\alpha$ is involved in the initiation and progression of the inflammatory response and the production of inflammatory mediators, such as IL-1 and IL-6 (25-27). Our findings are consistent with the results obtained by other investigators $(28,29)$.

The liver enzyme (ALT) was elevated in the serum, especially after 30 days of $N$. oleander treatment, indicating liver injury and disruption of hepatocyte membranes, which may be due to the liberation of free radicals by $N$. oleander $(18,30)$. LDH levels were also significantly increased, which could represent a good marker along with 
ALT, of tissue and cellular damage, especially hepatic cells.

$\mathrm{CK}$ is an essential enzyme in cellular energy transfer, helping in the transfer of high-energy phosphoryl groups in the mitochondria to generate ATP (31). The MB isoform of creatine kinase (CK-MB) is considered to be a specific indicator of myocyte injury and is elevated in myocardial damage (32). Jortani et al. (33) reported that oleander plants containing the cardiac glycoside oleandrin exert toxic effects via inhibition of $\mathrm{Na}^{+} / \mathrm{K}^{+}$-ATPase pump activity. In this study, CK and CK-MB were significantly elevated, indicating severe myocardial damage that may be due to cardiac glycoside inhibition of the $\mathrm{Na}^{+} / \mathrm{K}^{+}$-ATPase pump in the cytoplasmic membrane of cardiac cells, leading to positive inotropic effects and spontaneous depolarization in cardiac muscles (34). The inhibition of $\mathrm{Na}^{+} / \mathrm{K}^{+}$ATPase leads to an increase in the intracellular sodium concentration, which in turn induces an increase in the intracellular calcium concentration via the sodium-calcium exchanger. The sodium-calcium exchanger is particularly active in the myocardium and in vascular smooth muscles. The increase in intracellular calcium increases the force of contraction of the heart and vascular smooth muscles (35).

Our results were confirmed by histopathological examinations, which indicated several degrees of myocardial vacuolar degeneration, the loss of myofibril striation and inter-fascicular oedema. These findings indicate some degree of myocyte damage and myocardial injury after treatment with $N$. oleander, and these results are consistent with those observed by several researchers $(1,36,37)$.

Finally, we can conclude that exposure to $N$. oleander leaf extract adversely affects the heart and liver. The results showed significant adverse changes in haematological, biochemical and inflammatory parameters, as well as histopathological alterations. As this plant is used in the medical field, extra effort must be made to purify the effective chemical constituents to avoid toxicity.

\section{CONFLICT OF INTEREST}

All authors declare that there are no conflicts of interest related to this manuscript. This research is self-funded; we had no funding grants from any governmental or non-governmental organizations or institutes.

Received July 23, 2018; Revised November 20, 2018; Accepted December 22, 2018

\section{REFERENCES}

1. Taheri, S., Solati, A., Moradi, P., Tavassoly, A. and Yadi, J. (2013) Toxic effects of Nerium oleander aqueous leaf extract on haematological parameters and histopathological changes of the lungs and heart in rabbits. Comp. Clin. Pathol., 22, 1189-1193.
2. Karawya, M.S., Balbaa, S.I. and Khayyal, S.E. (1973) Estimation of cardenolides in Nerium oleander. Planta Med., 23, 70-73.

3. Galey, F.D., Holstege, D.M., Pulmee, K.H., Tor, E., Johnson, B., Anderson, M.L., Blanchard, P.C. and Brown, F. (1996) Diagnosis of oleander poisoning in livestock. J. Vet. Diagn. Investig., 8, 358-364.

4. Demiryurek, A.T. and Demiryurek, S. (2005) Cardiotoxicity of digitalis glycosides: roles of autonomic pathways, autacoids and ion channels. Auton. Autacoid. Pharmacol., 25, 35-52.

5. Osterloh, J., Herold, S. and Pond, S. (1982) Oleander interference in the digoxin radioimmunoassay in a fatal ingestion. JAMA, 247, 1596-1597.

6. Oji, O. and Okafor, Q.E. (2000) Toxicological studies on stem bark, leaf and seed kernel of yellow oleander (Thevetia peruviana). Phytother. Res., 14, 133-135.

7. Haeba, M.H., Mohamed, A.I., Mehdi, A.W. and Nair, G.A. (2002) Toxicity of Nerium oleander leaf extract in mice. $J$. Environ. Biol., 23, 231-237.

8. Aslani, M.R., Movassaghi, A.R, Mohri, M., Abbasian, A. and Zarehpour, M. (2004) Clinical and pathological aspect of experiment oleander (Nerium oleander) toxicosis in sheep. Vet. Res. Commun., 28, 609-616.

9. Tittel, G. and Wagner, H. (1981) Qualitative und quantatitve Analyse von Herzglykosiddrogen durch HPLC-Verfahren. Planta Med., 43, 252-262.

10. AOAC (1990) Official Methods of Analysis. Association of Official Analytical Chemists (AOAC), Washington, DC.

11. El-Olemy, M.M., Al-Muhtadi, F.J. and Afifi, A.F.A. (1994) Experimental Phytochemistry: A Laboratory Manual. King Saud University Press, Saudi Arabia, pp. 21-27.

12. Tor, E.R., Holstege, D.M. and Galey, F.G. (1996) Determination of oleander glycosides in biological matrices by HighPerformance liquid chromatography. J. Agric. Food Chem., 44, 2716-2719.

13. Bruce, R.D. (1987) A confirmatory study of the up-anddown method for acute oral toxicity testing. Fundam. Appl. Toxicol., 8, 97-100.

14. Singhal, K.G. and Gupta, G.D. (2012) Hepatoprotective and antioxidant activity of methanolic extract of flowers of Nerium oleander against $\mathrm{CCl}_{4}$-induced liver injury in rats. Asian Pac. J. Trop. Med., 5, 677-685.

15. Rahman, A., More, N. and Schein, P.S. (1982) Doxorubicininduced chronic cardiotoxicity and its protection by liposomal administration. Cancer Res., 42, 1817-1825.

16. Barbosa, R.R., Fontenele-Neto, J.D. and Soto-Blanco, B. (2008) Toxicity in goats caused by oleander (Nerium oleander). Res. Vet. Sci., 85, 279-281.

17. Altaee, M.F. (2011) In vivo toxicity study of Nerium oleander's leaves and flowers aqueous extracts in mice (cytogenetic, biochemical and hematological Study). Baghdad Sci. J., 8, 366-372.

18. Akhtar, T., Sheikh, N. and Abbasi, M.H. (2014) Clinical and pathological features of Nerium oleander extract toxicosis in Wistar rats. BMC Res. Notes, 7, 947.

19. Doi, K., Kurabe, S., Shimazu, N. and Inagaki, M. (1991) Systemic histopathology of rats with $\mathrm{CCl}_{4}$-induced hepatic cirrhosis. Lab. Anim., 25, 21-25. 
20. Hussein, A.M. (2016) The study of alkaloid extracts effect of Nerium oleander and Apium graveolens in the body Weight and blood parameters in laboratory mice females Mus Musculus L. Int. J. Agric. Sci. Res., 6, 87-96.

21. Jesri, A., Okonofua, E.C. and Egan, B.M. (2005) Platelet and white blood cell counts are elevated in patients with the metabolic syndrome. J. Clin. Hypertens (Greenwich), 7, 705-713.

22. Kim, M., Han, C.H. and Lee, M.Y. (2014) NADPH oxidase and the cardiovascular toxicity associated with smoking. Toxicol. Res., 30, 149-157.

23. Gullestad, L., Ueland, T., Vinge, L.E., Finsen, A., Yndestad, A. and Aukrust, P. (2012) Inflammatory cytokines in heart failure: mediators and markers. Cardiology, 122, 23-35.

24. Kang, G.J., Kang, N.J., Han, S.C., Koo, D.H., Kang, H.K., Yoo, B.S. and Yoo, E.S. (2012) The Chloroform fraction of Carpinus tschonoskii leaves inhibits the production of inflammatory mediators in HaCaT keratinocytes and RAW264.7 macrophages. Toxicol. Res., 28, 255-262.

25. Huong, P.T.T. and Jeon, Y.J. (2011) Macrophage activation by glycoprotein isolated from Dioscorea batatas. Toxicol. Res., 27, 167-172.

26. Basu, A., Sen, T., Ray, R.N. and Chaudhuri, A.K. (1992) Hepatoprotective effects of Calotropis procera root extract on experimental liver damage in animals. Fitoterapia, 63, 507- 514.

27. Wang, H., Wei, W., Wang, N.P., Gui, S.Y., Wu, L., Sun, W.Y. and $\mathrm{Xu}$, S.Y. (2005) Melatonin ameliorates carbon tetrachloride-induced hepatic fibrogenesis in rats via inhibition of oxidative stress. Life Sci., 77, 1902-1915.

28. Lange, G.L. and Schreiner, G.F. (1994) Immune mechanisms of cardiac disease. N. Engl. J. Med., 330, 1129-1135.

29. Torre-Amione, G., Kapadia, S., Lee, J., Durand, J.B., Bies, R.D., Young, J.B. and Mann, D.L. (1996) Tumor necrosis factor-alpha and tumor necrosis factor receptors in the failing human heart. Circulation, 93, 704-711.

30. Madkour, F.F., Khalil, W.F. and Dessouki, A.A. (2012) Protective effect of ethanol extract of Sargassum Dentifolium (Phaeophyceae) in carbon tetrachloride induced hepatitis in rats. Int. J. Pharm. Pharm. Sci., 4, 637-641.

31. Saks, V., Dzeja, P., Schlattner, U., Vendelin, M., Terzic, A., and Wallimann, T. (2006) Cardiac system bioenergetics: metabolic basis of the Frank-Starling law. J. Physiol., 571, 253-273.

32. Christenson, R.H. and Azzazy, H.E.M. (1998) Biochemical markers of the acute coronary syndromes. Clin. Chem., 44, 1855-1864.

33. Jortani, S.A., Helm, R.A. and Valdes. R. (1996) Inhibition of $\mathrm{Na}$, K-ATPase by oleandrin and oleandrigenin, and their detection by digoxin immunoassays. Clin. Chem. 42, 16541658.

34. Heard, K. (2004) Digoxin and therapeutic cardiac glycosides in Medical Toxicology (3rd edition) (Dart, R.C. Ed.). Lippincott Williams \& Wilkins, pp. 700-701.

35. Meyer-Lehnert, H., Bäcker, A. and Kramer, H.J. (2000) Inhibitors of Na-K-ATPase in human urine: effects of ouabain-like factors and of vanadium-diascorbate on calcium mobilization in rat vascular smooth muscle cells: comparison with the effects of ouabain, angiotensin II, and arginine-vasopressin. Am. J. Hypertens., 13, 364-369.

36. Yahaya, M.A., AL-Farhan, A.H. and Adam, S.E. (2000) Preliminary toxicity study on the individual and combined effects of Citrullus colocynthis and Nerium oleander in rats. Fitoterapia, 71, 385-391.

37. Aslani, M.R., Movassaghi, A.R., Janati-Pirouz, H. and Karazma, M. (2007) Experimental oleander (Nerium oleander) poisoning in goats: a clinical and pathological study. Iran. J. Vet. Res., 8, 58-63. 